\title{
A MAGYAR TANÁRKÉPZÉS A KÖZELMÚLTBAN ÉS A KÖZELJÖVÖBEN: A KRITIKA KRITIKÁJA
}

\section{HuNYADY GYÖRGY}

\author{
az Eötvös Loránd Tudományegyetem Pedagógiai és Pszichológiai Karának \\ professzora, akadémikus \\ hunyady.györgy@pk.elte.hu
}

\begin{abstract}
A bolognai rendszerü tanárképzés kritikai fenntartásokba ütközött, a bevezetését követö átmeneti megnyugvás után 2009-2010-ben elmérgesedtek a viták körülötte, és immár várható, hogy a szavakat tettek is követik. Formát öltött a tanárképzés átalakításának terve, a korábbról ismert módozatainak felidézése, miniszteriális koncepció került erröl közkézre és rövidesen jogszabályi elöterjesztések születnek. Konferencia-elöadásom tárgya az volt, hogy milyen ellenvetések merültek fel és milyen alapról indultak, ezt most megtoldom azzal, hogy az ellenreform tervei miben állnak és elöre láthatóan mire vezetnek. A kritika kritikája természetesen annak a keresését és azonositását is jelenti, hogy az egymást váltó és keresztezö reformok miben képvisel(het)nek folytonosságot.
\end{abstract}

\section{A bolognai rendszerü tanárképzéssel szembeni ellenállás természete és forrásai}

A bolognai rendszerü tanárképzés revizióját sokan, sok oldalról igényelték. Szerintük az osztatlan képzés visszaállítása e területen előnyös hatást fog kiváltani: kezdeteitől célirányosabbá teheti, kötöttségével szervezettebbé formálhatja magát a tanári hivatásra való felkészítést, a tanári pályára készülők külön útja megkönnyíti a kutatópályára készülők kiképzését is, kimentve öket az eltömegesedés visszafogó közegéből, sőt - egy értékelvü és nem piacorientált finanszírozás rendszerben - az egyetemet magától az eltömegesedéstől is mentesítheti, visszaállítva annak elitképző jellegét.

Ezt a gondolatmenetet toldják meg 2009/2010-ben a természettudományok reprezentánsai azzal a konkrét érvvel, hogy a tanári mesterképzésre szakterületükön - legalábbis néhány szakképzettség vonatkozásában - igen kevés a jelentkező. Nem igazán meggyőző, hogy a természettudományos területen mutatkozó csökkenő érdeklődés, az alapképzés eltömegesedésével járó nívótlanság és kibukás, valamint a diszciplináris mesterképzés viszonylag nagyobb vonzereje miért is kérdőjelezi meg a többciklusú képzés egész rendszerét, de a természettudományok müvelőinek önkörükben szerzett negatív tapasztalata az adott pillanatban fontos gyúanyagnak bizonyult. 
Azt sem mondhatjuk, hogy a tanárképzés többciklusú rendszerének koncepciójával, szabályozásával és gyakorlati bevezetésével szembeni ellenállás kizárólag „a természettudományos oldal” önmentő, önigazoló és önérvényesítő fellépéséböl adódik. A felsőoktatás nagyléptékü átalakításának része ez, és bizony az lenne csoda, ha azonnal lelkes támogatókra talált volna azokban, akik idegenkednek a nagy átalakítás piacra kacsintó funkcionalista jellegétôl, gyakorlatias mentalitásától, a képzés rendjét és az intézményes viszonyokat átszabó, rombolva építő hatásától. Az idegenkedés különösképpen alkalmas megjelölése a bolognai átalakításhoz füződő viszonyulásnak, hiszen mindennek együtt van egy kívülről jött, az európai együttmüködés követelményeiből levezetett, a német-orosz kulturális befolyási övezet megörökölt és megélt tradícióitól eltérő jellege is, rendszeridegen törekvéseket és tapasztalatokat képvisel.

A többciklusú tanárképzés súlyos tehertétele az alapképzés emésztetlen újszerüsége a magyar felsőoktatásban, amely az európai miniszterek intencióinak megfelelően tömegeket enged be a felsőoktatásba azzal a szándékkal, hogy müködőképes tudással viszonylag hamar jórészt kibocsássa őket, és erős belső szüréssel válassza ki a szellemi hivatások betöltésére alkalmas és törekvő elit fiatalságot. A tömeges hallgatóság kezelésének, jórészt gyakorlati irányba mutató értékei kiaknázásának, a tehetségek kiszürésének és felgyorsított elörehaladásának nem volt és röptében nem is születhetett meg a pedagógiai kultúrája a magyar felsőoktatásban. Sőt, ez nagyfokú tehetetlenséggel hurcolta tovább (mondhatjuk mindmáig) ismeretközlő és számonkérő metodikáját, berendezkedett szervezeti elrendezésének és egzisztenciális pozícióinak védelmére, ezzel is megkötve és túltöltve a tananyagot, kimerevítve a hallgatók értékelésének és az oktatók teljesítményének a mércéit.

A tanárképzés területén - az alapképzés tőle független és rajta túlnyúló problematikáján túlmenően - sajátos gond, hogy a hivatás tudatára és gyakorlatára felkészíteni rendeltetett pedagógia nem volt kívül-belül felkészülve arra a megnövekedett szerepre, amely a bolognai reform logikája szerint rá hárul. A neveléstudomány kiteljesedése - beleértve a pszichológia áttételében a természettudományokig elnyúló kapcsolatait, a tanári szakképzettségek szolgálatában álló szakdidaktikák szempont- és eszközgazdagságát - a mester-szintü tanárképzés legföbb biztositékainak egyike. Ez a feltétel ugyan nem teljesült maradéktalanul, de az kétségtelen, hogy a többciklusú képzés bevezetése és a tanári mesterképzésért viselt fokozott felelösség a neveléstudomány törzsterületén élénk pezsgést váltott ki, máris a tananyag gyökeres felfrissítésével járt és ezzel párhuzamosan a reform életet ébresztett a szakdidaktikák fonnyadásnak indult ágaiba is.

A tanári mesterszak bonyolult szövevény. Lassan, több szakaszban bomlott ki szabályozása, amely páratlanul széles hatósugarú, de szinte elvész a részletekben. A szervezeti épitkezés nehézkesen haladt, többhelyütt el-elmaradt, a törvényben elöírt intézményi koordináció esetlegesen alakult, de ott is, ahol - mint az ELTE-n - aprólékosan kimódolt testületi kontrollt sikerült kialakítani, az intézményi részérdekek 
és a szakmai szempontok diverzitása bénítóan hat a működésre és fejlesztésre. Az oktatók átlátásának hiánya, a dezinformáció, amely a reform útját végigkísérte, a közös ügyekkel és a kompromisszumos megoldásokkal való halvány azonosulás mind gátolja a munkaszervezés hatékonyságát. Nem vitás, ezen fékek nyomai az egyetemi élet más területén is fellelhetőek, de a tanárképzés esetében hatékony munkaszervezés nélkül egyszerüen széthull a képzés sok modulja, az elméleti és gyakorlati felkészítés, a közös cselekmények a felvételtől a képesítővizsgáig, a sokszínü oktatógárda és hallgatói tömeg.

Végül, de nem utolsósorban, a tanárképzés bolognai reformjának kiindulópontja az oktatási miniszterek között született európai megállapodás volt, Magyarország uniós felvétele elött elfogadott ajánlás. A felkínált séma mögött álltak praktikus megfontolások, de állt egy generális beállitódás is, amely egyfelöl a tudás és tanulás társadalmi szerepét honorálta, másfelől a mozgást és mozgékonyságot a gazdaságban és a szellemi fejlődésben (egymásra is vetítve e kettőt) felértékelte. Az előbbiből következik számszerúen a tankötelezettség életkori megemelése és a felsőoktatás (alapvetően az első ciklus) megnyitása a korosztály mind nagyobb hányada előtt. Az utóbbiból következik a munkaerőpiacok európai összenyitása és a munkaerő áramoltatása, de az is, hogy a hallgatóság képzőintézményen belül és képzőintézmények között, szakon belül és szakok között (önerejéből és saját felelősségére) szabadon kövezzen ki magának tanulmányi utat. Ennek a - mondjuk így - filozófiának jól megfelelt a tanárképzés hazai bolognai rendszerében a szakképzettségek (és a hozzájuk vezető modulok) szabad társítása, valamint a már felemlegetett lehetőség, a valamely szakképzettség mellett ugyanennek kínálata és felvétele „tanár idegen nyelven" változatban. Ez a nem realizált opció túlment azon, hogy képzésünk rendszerét deklarált elvek szerint közelítsük egy európai közös mércéhez, ez annak felvállalását is jelentette, hogy képezünk tanárt is az európai munkaeröpiacra. Ezt nagy nézetkülönbség választja el attól a felfogástól, hogy az iskola világa nemzeti keretbe zárt és nemzeti nyelvhez kötött, oly annyira - mint extrém megfogalmazásban hallhattuk is - hogy a tanár idegen nyelvtudása (minden más diplomástól eltérően) felesleges és mint követelmény elhagyható.

Ez utóbbi nézetben már benne rejlik egy jóval mélyebb fenntartás, amely csak a pedagógusképzés koncepcionális bírálatát követően, a közoktatási és felsőoktatási törvényalkotás átfogó munkálataiban nyert őszintén nyílt, explicit formát. E szerint a bolognai tanárképzés az oktatásra is túlköltö jóléti állam bukott gondolatát kombinálja egyfajta európai illuzionizmussal, mely nem teszi fel az alapkérdést: jó-e nekünk a munkaerő európai (ki)vándorlása, vagy realisztikusan a nemzeti munkaeröpiac (ma talán leginkább kétkezi gyakorlatra korlátozódó) tudásigényére képezzünk. E kérdésben való állásfoglalás - a teljes igazság igényével, vagy a részigazságok türésével - a tanárképzés ügyét, célját és feltételeit messzemenően befolyásolja, messze túl a „tanár idegen nyelven” szakképzettség - számomra különösen kedves, de - élettelen lehetöségén. 


\section{A bolognai reform néhány - a kormányzati ciklusokon túlmutató - időtálló eleme}

A bolognai reform elakad a közismereti tanárképzésben, a többciklusú képzési szerkezet felszámolásáról az oktatáspolitikai döntés lényegében megszületett. Ez azonban nyilvánvalóan nem(csak) lezárás, hanem nyitás, hiszen a félig-meddig jó emlékezetünkben élö reform-elötti múlthoz nem is tudunk és bizonyosan nem is akarunk visszatérni. Más ez a társadalom, mint volt a 70-es években az elágazó és osztatlan tanárképzés aranykorában, más ez a közoktatás, más a felsőoktatás szerepe és müködése, mások a hallgatók és más a világ, ahonnan hatások, vonzások és taszítások érik el öket, és ahol az általunk kiképzett tanároknak kultúrát kell közvetíteni, szakmai pályát kell befutni, ahol helyt kell állniuk.

Mi az, amit erőfeszítéseink nyomán, harcaink után, közös feladatként célul tüzhetünk magunk elé a tanárképzésben? Az „ELTE modell”-ben gyökerező bolognai reform főbb törekvései közül néhány időtállónak bizonyulhat:

- A tanári felkészítés legyen osztott vagy osztatlan, folyjék egyetemen vagy föiskolán, a képzés magasabb szintjével szembeni követelményeket teljesítsen, adjon minden árnyaltsága mellett egységesen mesterdiplomát.

- Meg kell öriznünk azt a szándékot és minden arra irányuló jó tapasztalatot, amely a tanárképzés gyakorlati jellegét, eszközeit, eredményeit erösíti.

- A szaktárgyi tudás és a pedagógiai felkészültség metszetében megkülönböztetett figyelmet érdemel a szakdidaktika, amelynek elfonnyadását kellő szervezeti kiemeléssel is meg kell akadályozni, általános informatikai eszközrendszerét és nevelésmódszertani beágyazottságát is biztosítani kell. Meg kell örizni a pedagógia tartalmi felfrissítésének és a tanárképzésért viselt felelösségtudatának felívelö lendületét, mint ami különösen fontos biztosítéka annak, hogy a leendő tanárok célszerüen készüljenek fel hivatásukra, és hatékonyan töltsék be közoktatási szerepüket.

- A tanárképzés mindig is több intellektuális alkotóelemet egyesít és több szervezeti egység kapcsolatában realizálódik. A tanárképző intézet - nevezzük bárhogy, és fogjuk össze a pedagógia, a pedagógiák oktatási szervezetével vagy épp világos kontúrral különítsük el attól - elengedhetetlen belső kapocs és külső kapcsolattartó a közoktatással és annak kormányzatával.

A képzés értékelendő minősége, a gyakorlati orientáció, a pedagógiai tudatosság és a képzés szervezeti összefogása olyan ambíciók voltak, amelyek kellő érvényesítésére hét év nem volt elegendő. De erős pszichológiai hatás az ún. Zeigarnikeffektus, a megszakított tevékenységekre többet és jobban emlékezünk, motivációja bennünk tovább él. 
A NEFMI előterjesztése - amely alapvetően a bolognai tanárképzési rendszer revizióját túzi ki célul - elhúzódó várakozás után kerül nyilvános egyeztetésre. Mintegy két éve tárgyalják különböző szakmai fórumok ennek az alapvonalaiban 2003-ban kimunkálni kezdett reformnak a látni vélt gyengéit.

\section{A tanárképzés NEFMI-koncepciójának problematikus tézisei}

A bolognai tanárképzés hazai változatának kidolgozásában - dokumentált pályázati munkában, az akkreditációs előterjesztések és elbírálásuk folyamatában - együttmüködött a felsőoktatás egész intézményrendszere, teljes szakértői gárdája, megküzdve azokkal a nehézségekkel, melyek a német-orosz oktatási kultúrában fogant duális rendszernek az angolszász típusú szisztémára való átállásakor jelentkeztek. $\mathrm{Az}$ átállás révén a tanárképzés európai fejlesztési trendje jelent meg nálunk, öszszemérhető, mégpedig kifejezetten versenyképes egyedi formában. Ezen strukturális változás során a) egységesen egyetemi/mester szintre került a tanárképzés; b) az iskolai terepen végzett gyakorlat bevezetésével a két ciklus (kredit) volumene meghaladta a hagyományos egyetemi kereteket is; c) a több alkotóelemből álló tanárképzés átfogó rendszerét erősítette meg az egyetlen tanári szak jogi formulája, melynek keretei között a pedagógiai-pszichológiai tanulmányok - a közoktatás újszerü feladataira való tekintettel - jelentősebb szerephez jutottak, mint korábban. Ezen koncepcionális döntésekkel lépett ki a magyar tanárképzés a 80-as, 90-es évek zilált állapotaiból és talált egyfajta megoldást dilemmáira.

A tanárképzés bolognai rendszerének müködését és hatékonyságát - mint erre a NEFMI-koncepció maga is utal - tapasztalati alapon tárgyszerüen megitélni ma még nem lehet, ennyiben a revízió merész vállalkozás. Az oktatási kormányzat belépése óta köztudottan hajlik arra, hogy a többciklusú képzésre való átállás radikális változásait legalább e téren felülvizsgálja: mindenekelőtt a természettudományos képzés területéről kapott következetes és erős impulzusokat, hogy az ott megélt problémákat (elsősorban a jelentkezők hiányát) a szakpárban folytatott osztatlan képzés visszaállításával orvosolja. Az oktatási kormányzat deklarált szándéka szerint minőségelvü (komoly erőfeszítéseket kíván tenni a tanárképzés színvonalának és rangjának erősítésére) és mérlegelő (végletesség nélkül igyekszik elérni lehetőség szerint a konszenzusos megoldásokat). Ugyanakkor a koncepció különbözö nyomásgyakorló csoportok véleményére hagyatkozva és hirtelen, erős kormányzati impulzusok hatása alatt nélkülözi a módszeres tapasztalatgyüjtés szakmailag biztos alapját és a nemzetközi perspektívát, és tudatosan törekszik arra, hogy korábbról ismert szerkezeti és müködési sémákhoz vezesse vissza a magyar tanárképzést. S eközben nincs kellően tekintettel arra, hogy azok a maguk korában beváltak-e, illetve az oktatásügy teljesen megváltozott köz- és felsőoktatási viszonyai között van-e realitásuk és értékük. 
A jogszabályi kimunkáláshoz közelitö koncepció jelen formájában - céljai és tervezett intézkedései között - ellentmondásos és nem koherens:

1. A pedagógusok minőségét többek között a minöségi kiválasztással kívánja biztosítani. A vonzó külföldi példák azonban oly körülményekre vonatkoznak, melyekben a pálya presztízse magas, a túljelentkezés óriási és ez szürési lehetőséget biztosít. E feltételek hazánkban hosszabb távon is legfeljebb csak remélhetőek, addig - épp velük ellentétben - a természettudományi területen a jelentkezők számszerủ hiánya mutatkozik immár hoszszabb távon. A mennyiségi minimum érdekében épp a természettudományi tanárképzés képviselői szorgalmaztak és szorgalmaznak teljesítmény-engedményeket az alacsonyabb felvételi pontszámtól a tananyag redukción át a mesterszint elötti szürés kiiktatásáig. Ezek az osztatlan képzésben jobban érvényesíthető tendenciák minőségi szempontból kontraszelektívek. Ráadásul arra sincs garancia, hogy a korai szakosodás a jelentkezők puszta számát garantálná (hiszen a ttk-ás terület tanári szakosodása a bolognai rendszer elveivel dacolva eddig is korai volt, a 18 éves kori döntést pedig eddig sem zárta ki semmi). A bölcsészettudományi területen a későbbi és erősebb (ön)szelekció az osztott rendszer előnyeit támasztja alá. A kiválasztás tekintetében tehát a tervezett változtatások gyors és biztos elörelépést egyáltalán nem igérnek.

2. A tanárképzés presztízsének és színvonalának előmozdítása érdekében az előterjesztés megőrzi a bolognai rendszer egységes tanárképzéséből a diploma rangját, mind az általános iskolai, mind a középiskolai tanárnak mesterdiplomát kíván nyújtani. A képzés azonban nem lesz egyenértékü, hiszen a képzési idő eltérő, és ezzel együtt az általános iskolai tanárnak (egy évvel több) kiegészítő képzésre van szüksége a középiskolai tanárrá váláshoz. A középiskolai tanár jogosítványai (feltehetően) tágabbak. Megtetézi e különbségeket, hogy a tanárok két válfaját különbözö jellegü és presztízsü intézmények képezik, a föiskolai kontextusban a tanári mesterképzés az egyetemitől eltérő szakmai-képzési környezetbe kerül (a zömmel ide szánt felsőfokú szakképzések közé, illetve a javaslat szerint a pedagógus alapképzéssel egyazon szervezeti keretbe). Az aktuális oktatáspolitikai elgondolások az intézménytípusok - európai tendenciákkal összhangzó közelítését kifejezetten keresztezik, a hierarchikus különbséget sarkítják. Ezzel a tanártársadalom megosztottsága nemhogy gyöngülne, hanem fel fog erősödni, aminek nem látni világosan a közoktatási értelmét és hasznát. Az általános iskola szerepének megszilárdításából (és a hat- és nyolcosztályos elitgimnáziumok számának limitálásából) épp az következne logikusan, hogy az általános iskolában, a szakiskolában, vagy netán a szakközépiskolában tanító tanárok felkészültsége nem maradhat el társaikétól. A képzőintézmények nézőpontjából az általános iskolai és a középiskolai tanárok 
képzésének szétválasztása azt jelenti, hogy a főiskolák szakmai ambíciójukból és akkreditált tanárképzési jogosultságukból veszítenek, az egyetemek pedig az amúgy is szükülő hallgatói létszámból vesztenek, miközben a különböző tanári, illetve diszciplináris képzések szétválasztása az oktatási kapacitásukat többszörösen igénybe veszi. A tanárok kategóriáinak megkülönböztetése és képzésük szétválasztása oktalan megosztottságot teremt a közoktatásban, és károsan érinti a felsőoktatási intézményeket.

3. A föiskolai/általános iskolai és egyetemi/középiskolai tanárképzés eltérése - az előterjesztés felfogásában - nem lényegi és nem kellően megokolt. A diszciplináris ismeretanyag kreditmennyiségében van köztük különbség, és várhatóan ezt hidalja át a kiegészítő képzés jórésze is. (Közbevetőleg megjegyzendő, hogy a koncepcionális előterjesztés kevesellte a korábbi föiskolai végzettség egyetemi szintre emelésében az egyéves, 60 kredites képzést egy szakon, ezzel szemben a jövőre vonatkozóan két szakon ennek dupláját írja elő - szinte végtelenítve a tanárképzést.) Miközben az egységes tanárképzés „visszabontását”, kettőbe választását az előterjesztés az általános és középiskolai pedagógiai feladatok markáns különbségével indokolja, a pedagógiai jellegü képzés volumenében nem tesz különbséget a kétféle tanárképzés között. Amint erről már szó esett, valószínüsíthető, hogy a középiskolai tanár felkészültsége elegendő lesz az általános iskolai oktatáshoz-neveléshez, ez azonban nem viszonos: az általános iskolai tanár nem kap jogosítványt a középiskolai feladatok megoldására. Ez az aszimmetria nem indokolható. Talán egy olyan elöfeltevést rejteget, hogy a diszciplináris tudás fél-félévnyi többlete az azonos volumenủ pedagógiai felkészités értelmét és hatékonyságát is magával húzza-vonja. A pedagógiai-pszichológiai felkészítés tartalma egyébként az általános iskolai tanárképzés esetében sem szorítható be meghatározott életkor sajátosságainak a problémakörébe, hanem ennél általánosabb és teljesebb mind a kompetenciák, mind a fejlödéstrendek megismertetésében. Az általános iskolai és a középiskolai tanárok képzése közötti különbség pedagógiai-pszichológiai vonatkozásban nem jelentkezik, és szakmailag nem is lenne tartható.

4. A koncepció az elöírt pedagógiai-pszichológiai tanulmányok mértékét, részarányát, a képzés folyamatában elfoglalt pozícióját lerontja, annak ellenére, hogy épp a pedagógiai feladatok nehézségére és sajátszerüségeire hivatkozik a tanári mesterség növekvő társadalmi felelőssége és súlya mellett érvelve. A képzés volumene a bolognai rendszerü tanárképzéshez képest is tovább nő, a gyakorlatra hivatkozva, ám a gyakorlatot valójában a bolognai rendszerü képzés szintjén tartja. A némileg csökkentett pedagógiai modul felerészt a képzési folyamat gyakorlatra szánt utolsó szakaszán - appendixként - kerül sorra, ami elméleti alapozó és szemléleti orientáló 
szerepét nagyban korlátozza. A bolognai tanári mesterszakkal szemben egyik legfőbb kritika az volt, hogy előtérbe helyezi a diszciplináris alapozást, későn lát hozzá a pályára való szocializáláshoz, és a tág értelemben pedagógiai stúdiumok a képzés utolsó szakaszán torlódnak - mindezt a kilátásba helyezett korrekció nem haladja meg. A koncepció alighanem a tételes tárgyi tudást és az ismeretközvetitést tekinti a tanári-felkészités gerincének, és ezzel azt az utat követi és folytatja, amelyen a természettudományos tanárok képzése eddig is járt, és a sikertelenség mai állapotába jutott. A képzés strukturális átalakításában figyelmét a két tanári képesítés szigorú szimmetriájának biztosítása köti le, tekintet nélkül az oktatandó diszciplínák közötti kapcsolatok konkrét tartalmára (pl. a biológia tanulása mennyi kémiai tudást feltételez és nyújt, a fizika mennyi matematikát követel és rejt magában, amit is a biológia-kémia vagy fizika-matematika jellegzetes szakpárok felépítésekor a formális kreditegyenlőségen túllátva számításba lehetne és kellene venni). Mint ahogy nincs tekintettel a tanulás különböző területei közötti tudás-transzferre sem. A mereven arányosított diszciplináris képzés és a hozzá kapcsolódó szakmódszertan gyarapodik, a képzés alkotó elemeinek arányai eltolódnak. Kérdés, hogy a közoktatás szakismeretben szenvedett-e hiányt, vagy épp a pedagógiai hatékonyság, tudatosság, kultúra megerősítése a legégetőbb. A közoktatási igények a pedagógiai érzékenység és hatékonyság növelését diktálnák, ezzel szemben kifejezetten és egyoldalúan a diszciplináris tudás és az ismeretközvetités erösitésére kerül sor a pedagógiai-pszichológiai felkészités rovására.

5. A bologna rendszerü tanárképzés bevezetése nagyléptékü, radikális változtatás volt, ami sok vonatkozásban ellenállást váltott ki, és ez fenn is maradt. Revíziója ugyan sokak egyetértésével találkozik, de hogy történetileg hová és meddig hátráljunk belőle vissza, az egy joggal vitatott kérdés. Az osztatlan képzés részleges vagy teljes felszámolásával sokan egyetértenek, bár ennek is - elsősorban a pedagógia nemzetközi kitekintéssel rendelkező mủvelői között - számottevő az ellentábora. A váratlan fordulat viszont, hogy a 60-as és 70-es évek módjára különítsük el az általános iskolai és a középiskolai tanárképzést, az egységessel szemben állítsuk vissza a tanárképzés duális rendszerét, többoldalú ellenvéleménybe ütközik, ezzel kapcsolatban ma egyáltalán nem lehet konszenzusos támogatásról beszélni.

A képzés lebontása és átépítése az előterjesztés szellemében roppant munkát követel a jogalkotástól, a minisztériumi és intézményi jogalkalmazóktól a szabályozás, tanterv- és tananyagfejlesztés, a dokumentáció és akkreditálás, a szervezés és koordináció területén. A bolognai rendszer bevezetése sokak szemében eröltetett menet volt, és így is 7 évet vett igénybe, ebböl következően a megfontolt változtatás sem igényel kevesebb munkát és időt. A tanárképzés átalakítása maga, az átme- 
neteivel és a létesítésre és beüzemelésre váró rendszerével - minden jel szerint igen költséges lesz. Ennek egyaránt oka az egyre növekvő volumen, a gyakorlathoz kötődő munkaformáinak intenzitása, a tartalmilag rokon kurzusok széttagoltsága. $\mathrm{Az}$ a kérdés, hogy az elérhető változások szellemi és társadalmi hozama igazolja-e ezt a kiemelkedö munka- és anyagi ráforditást, vagy sem. A képzési szerkezetnek az előterjesztésben leírt átalakítása ezt az erőbevetést önmagában aligha éri meg, csak akkor, ha a pedagógiai modult követóen most sor kerül a szakmódszertani terület szisztematikus fejlesztésére, a diszciplináris tartalom közoktatási (NAT) szempontból célszerü kimunkálására, a gyakorlati képzés feltételeinek és követelményeinek folytatólagos formálására. A felsőoktatási tartalomfejlesztés és a közoktatási beválás-vizsgálat az, melynek alapján a bolognai rendszer szerepét megitélni és gyengéinek revizióját kezdeményezni és irányitani kell, e nélkül a képzési szerkezet módositása öncélú és ráfizetéses.

\section{A bolognai rendszert lebontó változtatások néhány valós és potenciális pozitívuma}

A kormányzati koncepció korrekcióra szoruló problematikus vonásai mellett említést és támogatást érdemel több pozitív eleme, melyek előrelépést ígérnek:

1. Az elvek szintjén elismerésre méltó az a törekvés, hogy a pedagógusképzés általában és a tanárképzés konkrétan célirányosan szolgálja a közoktatás ügyét. Az országos szintü összerendezés mellett és annak szerves kiegészítéseként helyeselhetö a tanárképzés intézményi szervezeti kiemelése, a rektor-közvetlen és a karok között koordináló Tanárképzési Központ elöírása. A jelenlegi heterogén helyzet hosszas leírását követi az előterjesztésben ezen szervezeti megoldás előírása, amely a tanárképzés rendszerbeállításának, jogkövető müködtetésének, tartalmi összehangolásának és fejlesztésének, a széthúzó kari érdekek kordában tartásának, a közoktatással való élő kapcsolattartásának a garanciája lehet. (Zavaró az egyetemi közegben szükséges Tanárképzési Központok létesítése mellett a Pedagógusképző Föiskolák felvetett, más irányú szervezeti és képzési integrációja.)

2. Célszerü a pedagógiai-pszichológiai, szakmódszertani és gyakorlati stúdiumok kereteinek kijelölése, aminek az előzményei a ma már általánosan elfogadott 111/97-es kormányrendeletig nyúlnak vissza. A szakmódszertan szerepe és szakmai színvonala fokozott figyelmet érdemel, ehhez azonban a sokhelyütt leépült szervezeti-személyi kereteit fel kell frissíteni, egyenetlen tudományos színvonalát és utánpótlását fel kell javítani, a közoktatási gyakorlathoz füző életszerü kapcsolatait erősíteni kell (pl. a gyakorló iskolák ezen kapacitásainak intézményes bevonásával). Amikor a szakmódszertan volumenét és hatékonyságát az előterjesztés kiemeli, szembe kell nézni azzal a ténnyel, hogy e teret a szakmódszertan csak cél- 
irányos fejlesztés révén és után tudja betölteni, és ez átgondolt intézkedéseket követel.

3. A tanártovábbképzést a képzés szerves és szervezett folytatásának kell tekintenünk és a felsőoktatási képzőintézmények aktív és felelös közremüködése e téren valóban nélkülözhetetlen. Ez teremti meg az előfeltételét az alapképzés akár diszciplináris, akár tág értelemben pedagógiai kiteljesítésének, ami nem egyszerüen hiánypótlás, hanem a szakmai fejlödés logikus és természetes útja. Ha például nem látható elöre, hogy a végzett tanár pályájának valamely fázisában milyen iskolatípusban dolgozik, akkor a továbbképzés tudja majd hozzásegíteni a tapasztalatai gyüjtésében, kiértékelésében és fejlesztésében kamatozó specifikus tudáshoz és felkészültséghez. Ugyanakkor a felsőoktatási intézmények/Tanárképző Központok ezen szerepe a maga tapasztalataival fontos visszacsatolást és motivációt nyújt majd a tanári alapképzés fejlesztésének.

4. A közoktatás józanul kalkulálható igényeire tekintettel indokolt, hogy az előterjesztés a képzöhelyek számát - a kiegyenlített feltételek, hatékonyság és teljesítmények érdekében - limitálja, és a megszerezhető tanári végzettségek változatosságában rendet vágjon. Az általános iskolai tanárképzés bázisául az egykori föiskolák felsorolása szerepel a koncepció megismert szövegében, tekintet nélkül arra, hogy egyetembe integrálódva közismereti tanárképző profiljukat mennyiben őrizték meg (ld. például Szeged), vagy önállóan mennyiben teljesítették azt ki (ld. Eger, amely időközben jelentős diszciplináris fejlesztésen esett át, és közvetlenül az ELTE mellett a legteljesebb képzési portfolióval rendelkezik a mai tanári mesterképzésben). A gimnáziumok tanár-utánpótlási igényeihez mérve a középiskolai tanárokat képző egyetemek száma nagy és kapacitása meg kifejezetten óriási (még az is meglehet, hogy például az ELTE természettudományi területére alig esik majd több államilag finanszírozott hallgatói hely, mint ahány - botrányosnak tünően kevés - jelentkező mutatkozott az utóbbi években). A zömmel eddig „kizárólag második szakként” szereplő tanári végzettségek átminősítése harmadikká, illetve továbbképzési szakká, a két tárgyat oktató közismereti tanár prototípusának kiemelését szolgálja. (Az rejtély, hogy miért nem oktatható harmadik szakként az Ember és társadalom integrált stúdium, ha az Ember és természet szerepelhet ebben a minőségben. A csak benne megjelenített pszichológia ilyen módon kiesik az olyan közismeretiként elfogadott szakképzettségek sorából, mint pl. a filozófia és a pedagógia. Holott a Környezettanhoz hasonlóan egy érdemi tartalmi felülvizsgálat során akár az is mérlegelhető, hogy akár első-második szakként is része és segítője lehetne a tudományos világlátásnak, legalább oly joggal, mint a román vagy a technika.) 
5. Kiemelt figyelmet érdemel az elöterjesztés azon törekvése, hogy rugalmasan türje a tanárképzés különböző formáinak egymásmellettiségét és ezzel is összefüggésben a hallgatók szabályozott átjárását a képzés különbözö útjai között, a tanárképzésen belül és e körön túl. A bemenetnél teljesítmény-alapon szürt felsőoktatáson belül tere kell legyen a hallgatók önmagukért felelösséget vállaló és viselő szakmai mozgásának. Ez lehet egyébként az egyik legföbb biztosítéka annak is, hogy a tanárszak több oldalról kap később érlelődő utánpótlást, és ugyanakkor a kiút megnyitásával nem lesz sokak számára kényszerpálya, amelyen kényszeredetten elindulnak, de ahonnan a közoktatásba nem érkeznek el (vagy jobb, ha nem érkeznek el). A sokak által igényelt és az erősen beszúkülő gimnáziumi tanár-utánpótlás szempontjából különösen releváns tudóstanár képzésének például kézenfekvő és szükséges útja a diszciplináris mesterképzésre ráépülö (egyszakos) tanári kiképzés (második mesterdiploma).

A szakmai és müvészeti tanárképzésben a bolognai rendszerü osztott tanárképzés fennmarad, illetve az osztott és osztatlan formák müködnek az intézmény döntésétől függően. Ennek analógiájára rendezhető a közismereti tanárképzés is: ha az alapvető közismereti szakokon szimmetrikus párba állított osztatlan képzések is folynak, ez önmagában még nem jelenti azt, hogy ugyanezeken a kiemelt jelentöségü szakokon hosszabb távon már nem müködhet az alapképzésben résztvevők csoportjának alternativ utat felkínáló osztott tanárképzés (például a bölcsészettudományi területeken, ahol létszámproblémák sürgető orvoslására generálisan nincs szükség). Akár rendszerszinten elöírható lehet osztott képzés a nem-szokványos szaktársitások esetén (mint mondjuk angol-fizika vagy filozófia-matematika). Ezért is az osztatlan bologna-előtti forma bevezetését szükségtelen, sőt helytelen lenne kizárólagossá tenni. Ha a megválasztás lehetősége és az intézményi mozgástér - a Tanárképzési Központ kemény szabályozása mellett - fennmarad, akkor válik valósággá az előterjesztésnek azon zárógondolata, hogy a különböző formák egymásmellettisége teremthet - ma kétségtelenül nélkülözött - tapasztalati alapot ezek beválásának tárgyszerü megítélésére.

\section{A kritikai szemle összefoglalása}

Ma még nincs szilárd tapasztalati alapja a bolognai rendszerü tanárképzés elbírálásának és revíziójának. A múltból ismert tanárképzési szerkezet visszaállítása öncélú és ráfizetéses, ha nem szolgálja bizonyítható módon a közoktatás igényeinek jobb kielégítését. A tág értelemben vett pedagógiai felkészítés (beleértve a sorvadásnak indult szakmódszertant) a közoktatás szolgálatában legalább olyan fontos, mint a leendő tanárok diszciplináris tudásának erősítése. Az általános iskolai és középiskolai tanárok megkülönböztetése, és elkülönített felkészítése egy duális rendszerben, megosztottságot teremt a közoktatásban, és károsan érinti a felsőoktatási 
intézményeket. Az osztott és osztatlan tanárképzés együttes müködtetése a kívánatos a közismereti tanárképzésben is, ez nem idegen a nemzetközi gyakorlattól sem, és olyan helyzetet teremt, amelyben tárgyszerüen össze lehet mérni a különbözö képzési formák hatékonyságát. Támogatást érdemel a tanárképzés rendszerszerü müködtetése országosan és a képzőintézményekben, így a felsőoktatási Tanárképző Központok felállítása és ezek aktív szerepvállalása a tanártovábbképzésben. 